\begin{tabular}{l|c|c}
\hline EREM 76/4 & \multicolumn{2}{|c}{ Impact of Sewage Sludge Leaching on Soil Constituents and Quality } \\
\cline { 2 - 3 } $\begin{array}{l}\text { Journal of Environmental Research, } \\
\text { Engineering and Management } \\
\text { Vol. 76/ No. 4/ 2020 }\end{array}$ & Received 2020/04 & Accepted after revision 2020/11 \\
$\begin{array}{l}\text { pp. 87 } 96 \\
\text { Dol 10.5755/j01.erem.76.4.25632 }\end{array}$ & Cross & http://dx.doi.org/10.5755/j01.erem.76.4.25632 \\
\cline { 2 - 2 }
\end{tabular}

\title{
Impact of Sewage Sludge Leaching on Soil Constituents and Quality
}

\section{Zahra Zerrouqi*, Mohammed Reda Tazi}

Regional Center for Education and Training, Hay Al Massira, Oujda, Morocco

\section{Abdelhafid Chafi}

Faculty of Sciences, Boulevard Mohamed VI - B.P: 717, Oujda, Morocco

\author{
Abdessamad Zerrouqi \\ Medical University of Warsaw, Warsaw, Poland
}

${ }^{*}$ Corresponding author: zzerrouqi@yahoo.fr

Activated sludge treatment plants generate large quantities of sludge each year, thereby posing a serious environmental problem. This study aims to experimentally assess the effect of rainwater on the leaching of sludge components. In this context, a percolation test was set up, and composed of PVC cylinders into which the solid substrate was introduced. Five modalities of the solid substrate were used: a sludge modality, a soil modality and three modalities with increasing percentage of sludge (1\%,5\% and $25 \%)$ in the soil. The percolation water is collected during the rainy months in bottles placed below each column. Solid substrate samples were taken before the test and after one year. The physicochemical analysis of the percolation water showed an increase in the electrical conductivity, $\mathrm{BOD}_{5}, \mathrm{COD}$, nitrogen compounds and phosphate compounds which were proportional to the percentage of sludge. The $\mathrm{pH}$ of the sewage sludge leachates varies from 7.61 to 7.98. Zinc and copper were the most mobilized metals. A year following the installation of the percolation test, electrical conductivity, total phosphorus (TP) and orthophosphate $\left(\mathrm{PO}_{4}\right)$ contents decreased for the solid substrates using the five modalities. Furthermore, ammonium $\left(\mathrm{NH}_{4}\right)$ and nitrates $\left(\mathrm{NO}_{3}\right)$ levels decreased in soil mixed with 1 to $25 \%$ of sludge due to their leaching by rainwater. Collectively, these data show that the leachates through the soil mixed with sludge are stable and loaded with $\mathrm{NO}_{3}$, a plant nutrient that can contaminate the groundwater as well as the surface waters inducing their eutrophication. Furthermore, addition of sludge to the soil improves the levels of carbon, total nitrogen, $\mathrm{TP}$ and $\mathrm{PO}_{4}$ in the soil and thereby soil fertility. The addition of sludge, however, is not without soil contamination with heavy metals. Such soil contamination would cause pollution of surface and ground water. Reaching certain severity, it should call for the adoption of prompt measures for the protection of environment and human health.

Keywords: sludge, leachate, soil, heavy metals, nitrates, percolation. 


\section{Introduction}

The expansion of urban regions is incessantly generating alarming amounts of sewage that require appropriate treatment. The plants destined for sewage treatment generate a high amount of liquid and highly fermented waste, known as sewage sludge. In 2014 , the sewage sludge quantity was around 392.000 tonnes of wet sludge in Morocco and is estimated to reach 2 million tonnes of sludge at 25\% dryness per year by the year 2030 (Netherlands Enterprise Agency, 2018). Such continuous accumulation of sludge would dramatically impact the environment (Fuentes et al., 2004; Dong et al., 2015). Therefore, various processes are used to dispose of the sludge: incineration, land filling or agricultural spreading. The sludge contains compounds such as carbon, nitrogen, phosphorus and potassium (Lambkin et al., 2004). Many researchers have reported a positive impact of using sewage sludge in agriculture (Wu et al., 2015; Kominko et al., 2017), reconditioning of degraded natural and anthropogenic soil (Martínez et al., 2003), control of erosion as well as slope stabilization (Sort and Alcañiz, 1999). However, the recycling of sewage sludge into agricultural land has serious risks for public health and environment. The sewage sludge contains high amounts of toxic metals (Cesar et al., 2012). These sludge constituents are subjected to leaching by rainwater (Vettorazzo et al., 2001; Lehmann et al., 2003), and thereby liable to contaminate soil, water, and produce (Keller et al., 2002; Lavado et al., 2007), which limit the use of sludge in agriculture (Chaudri et al., 2000; Mosquera-Losada et al., 2010).

The City of Nador, located in the northeastern region of Morocco, is equipped with wastewater treatment plants (WTP) using activated sludge process. The Nador's sludge is disposed in landfill as seen in other WTPs in Morocco (Arisily and Hajji, 2020). Sludge, generated from the Nador's WTP, can be used in farming as fertilizer in the plains of Bou-Areg and Gareb, located in the Moulouya basin in the south of Nador city. However, under these two plains there is a shallow aquifer, which extends continuously and covers an area of 570 $\mathrm{km}^{2}$. Unlike that of the Gareb aquifer, the thickness of Bouareg aquifer varies from 5 to $60 \mathrm{~m}$ only (Lyazidi et al., 2019), thereby increasing the risk of its pollution by sludge leachate.
The objective of this research is to determine the physicochemical characteristics of sewage leachates in comparison with soil leachate, and assess its impact on the soil. We will use experimental models of leaching sludge by rainwater to assess the transfer of nutrients and toxic elements from sewage sludge, generated by water treatment plants of Nador city (Morocco).

\section{Methods}

In order to provide more information about the importance of sludge leaching by rainwater, a percolation test was carried out. The experimental test setup consists of a polyvinyl chloride (PVC) column (microcosms), one meter high and an internal diameter of 10.5 $\mathrm{cm}$, into which the solid substrate was introduced. Five modalities of the solid substrate were used: a sludge modality $(100 \%$ S) used to understand the effects of sludge stocks on water resources, a control modality consisting solely of soil ( $0 \%$ sludge) and three modalities with increasing percentages of sludge (1\%,5\% and $25 \%)$. The soil used for the experiment, comes from an agricultural plot that has never received sewage sludge or irrigated by sewage. This soil was collected at a depth of $0-40 \mathrm{~cm}$, dried in the open air and sieved to $2 \mathrm{~mm}$. The sludge used in the percolation test comes from a sludge stock of the Nador's WTP. The column of the solid substrate weighs $2.75 \mathrm{~kg}$ each and measures approximately $25 \mathrm{~cm}$ in height. The microcosms were placed in the open air for one year.

Below, a mesh of fabric holds the ground column while allowing a good drainage of the water. The percolation water was collected in bottles placed below each column in the same day. The percolates collected during five rainy months (January to May) were subsequently filtered and stored at $4^{\circ} \mathrm{C}$ to be analyzed the following day. The samples intended for the determination of heavy metals were acidified to $\mathrm{pH} 2$ with $\mathrm{H}_{2} \mathrm{SO}_{4}$.

The leachate samples subjected to the percolation test underwent several analysis: $\mathrm{pH}$, electrical conductivity (EC), salinity, ammonium $\mathrm{NH}_{4}$ (NF T90-015), nitrates $\mathrm{NO}_{3}$ (Rodier, 1984), orthophosphate $\left(\mathrm{PO}_{4}\right)$ and total phosphorus (TP) (NF T90-023), total Kjeldahl nitrogen 
(TKN) (NF T90-110), chlorides (NF T90-0114), sulfates $\left(\mathrm{SO}_{4}\right)$ (Tardat-Henry and Beaudry, 1992) and chemical oxygen demand (COD) (NF T90-101). Biochemical oxygen demand $\left(\mathrm{BOD}_{5}\right)$ was determined after incubation at $20^{\circ} \mathrm{C}$ for five days. Water soluble heavy metals were analyzed after filtration using inductively coupled plasma emission spectrometry (ICP-AES). The results were generated from the analysis of leachate samples $(n=$ 8), carried out during the five months of monitoring are expressed as average value. The sampling was carried out after rain. Table 1 shows the number of percolate samples taken per month. Eight samples in total were analyzed.

Table 1. Number of leachate samples

\begin{tabular}{l|c|c|c|c|c}
\hline & January & February & March & April & May \\
\hline Sample numbers & 1 & 2 & 1 & 1 & 3 \\
\hline
\end{tabular}

Substrate samples were taken from the $0-10 \mathrm{~cm}$ layer, tested at the time of collection and after one year using the five modalities in order to check the impact of rain leaching on nitrogen and phosphate levels. Afterwards, the samples were subjected to several physicochemical analysis. The $\mathrm{pH}$ measurement is carried out on a substrate-water mixture with a ratio of $1 / 5$ (volume / volume). The mixture is stirred for $5 \mathrm{~min}$ and left to rest for 2 hours (ISO 10390). Electrical conductivity and salinity are measured on a substrate-water extract with a ratio of $1 / 5$ (mass/volume) after stirring for $30 \mathrm{~min}$ (ISO 11265). The extraction of the mineral nitrogen is carried out with a $2 \mathrm{M} \mathrm{KCl}$ solution (Keeney and Nelson, 1982). The forms of mineral nitrogen $\left(\mathrm{NH}_{4}, \mathrm{NO}_{3}\right.$ and $\left.\mathrm{NO}_{2}\right)$ in extracts are analyzed by colorimetry assay according to the methods described for leachate. Total nitrogen is measured according to the Kjeldahl method (NF ISO 11261: 1995). Orthophosphate is extracted from solid substrates in distilled water with a ratio $1 / 10$ substrate/ water and stirred for 1 hour (Self-Davis et al., 2000). The assay is performed using the standard (NF T90-023). The total phosphorus is always determined using the NF T90-023 standard after mineralization of organic phosphorus into orthophosphate ions (Olsen and Sommer, 1982). Total organic carbon (C) is measured by the Walkly and Black method (Gigliotti et al., 2001).
Heavy metals are analyzed by Inductively Coupled Plasma Atomic emission spectrometry (ICP- AES) ICP (after mineralization with aqua regia $\left(\mathrm{HNO}_{3}\right.$ and $\mathrm{HCl}$ with a ratio of 1:3) (EPA-ROC, 1994).

\section{Results and Discussion}

\section{Characteristics of leachate sludge}

\section{$\mathrm{pH}$, electrical conductivity and salinity}

Generally, leachate is considered a high strength wastewater with high conductivity, rich in ammonium and organic matter. It can be described as a multi-component mixture of insoluble, soluble, inorganic, organic, non-ionic, ionic, bacteria and bacteriological substances in an aqueous solution. Since these components are water soluble, there is a high risk that they will leak in surface and groundwater (Dounavis et al., 2019).

Among the factors that affect the composition of the leachate is the $\mathrm{pH} . \mathrm{pH}$ is known to influence the mobility of heavy metals in the environment (Bourg and Loch, 1995). However, its effect on the concentration of heavy metals in soil solution differs among metals. The analysis of the sludge leachate collected during the monitoring period is shown in Table 2. We found a slight variation in $\mathrm{pH}$ between the five modalities studied. The $\mathrm{pH}$ difference between soil versus soil mixed with sludges (at 1\%,5\% and 25\%) varies from 0.01 to $0.16 \mathrm{pH}$ unit (Table 2).

The electrical conductivity $(E C)$ was also measured. The results show increased EC as salinity tied to the sludge percentage increases from $2.38 \mathrm{mS} / \mathrm{cm}$ for the soil modality to $15.17 \mathrm{mS} / \mathrm{cm}$ for the sludge modality. Conductivity values are strongly related to the total salts content in leachate reflecting its total concentration of ionic substances. In fact, the elevation of EC and the salinity of sludge percolates can be explained by the importance of the leaching through the sludge of mineral salts such as sulphates, chlorides and nitrates.

\section{$\mathrm{Ca}, \mathrm{Mg}, \mathrm{Na}, \mathrm{K}, \mathrm{SO}_{4}, \mathrm{Cl}$}

The biodegradation and mineralization of organic matter involves the production of nutrients through microbial communities (bacteria, fungi) and the release of assimilable elements ( $\mathrm{K}, \mathrm{Ca}, \mathrm{Mg}, \mathrm{K}$, etc.). The most 
leached anions are sulphates $\left(\mathrm{SO}_{4}\right)$. Sulphates are generally strongly present in leachates (Robinson and Lucas, 1985). We found that their concentration in sludge leachates was found to be 22 times higher than in soil leachate. Sewage sludge contains a significant concentration of sulphur. Various authors (Sommers et al., 1977; Gutenmann et al., 1994) report a total sulphur concentration in waste sludge between 0.3 and $2.3 \%$ on a dry solid basis. The most dominant inorganic sulphur containing molecules are sulphates and (metal-) sulphides. Moreover, some sulphur is incorporated in the organic material (Dewil et al., 2008). Due to their high mobility (Lehmann and Chroth, 2003), the sulphates would ultimately enrich the leachates: the fall of rain on sludges would lead to significant leaching of sulphates. Chlorides $(\mathrm{Cl})$ are often considered as conservative and inert species (Christensen et al., 2001) and their contents do not generally depend on the different phases of waste degradation. Chloride ions are highly mobile elements. Negatively charged, they are not fixed by the clay-humic complex and migrate easily. These facts may explain our data as the concentration of chloride $(\mathrm{Cl})$ was 1.5 times in sludge percolate higher than in soil percolate (Table 2).

We found that the most leached cation is calcium. Its concentration increased from $212.2 \mathrm{mg} / \mathrm{L}$ for leachate soil to $369.9 \mathrm{mg} / \mathrm{L}$ for sewage sludge percolate (Table 2).

In summary, the leached concentrations of the studied anions and cations were almost proportional to the percentage of sludge in the solid substrates.

Organic matters are usually quantified as $\mathrm{BOD}_{5}$ and $\mathrm{COD}$ (Lee and Nikraz, 2014). We found that the rate of sewage sludge positively correlates with $\mathrm{BOD}_{5}$ and the $\mathrm{COD}$ (Fig. 1). Indeed, $\mathrm{BOD}_{5}$ and $\mathrm{COD}$ increased from $50 \mathrm{mg} / \mathrm{L}$ to 364 $\mathrm{mg} / \mathrm{L}$ and from $454.9 \mathrm{mg} /$ : to $3129.6 \mathrm{mg} / \mathrm{L}$ for soil leachate and sewage sludge leachate, respectively. The increase in $\mathrm{BOD}_{5}$ and $\mathrm{COD}$ of sludge leachate can be attributed to the increase in microbial activity and the amounts of leached organic matter after the rainfall. In fact, the activity of microorganisms is found to be stimulated by the addition of sludge (White et al., 1997). The increase of this microbial activity is likely responsible for the high concentration of water-soluble organic molecules, which could have been carried along by the percolation water.

The $\mathrm{BOD}_{5} / \mathrm{COD}$ ratio can be considered as a measure of the biodegradability of the organic matter, and hence of the maturity of the leachate, which typically decreases with time (Quasim and Chiang, 1994). High $\mathrm{BOD}_{5} / \mathrm{COD}$ ratios indicate elevated concentrations of biodegradable organic compounds, while low $\mathrm{BOD}_{5} / \mathrm{COD}$ ratios indicate a resistance to biological degradation due to the predominance of non-biodegradable compounds (Bhalla et al., 2013). A $\mathrm{BOD}_{5} / \mathrm{COD}$ ratio greater than 0.5 indicates an unstable leachate, whereas when the ratio is less than 0.1 , the leachate can be considered mature (SWANA, 1997). For the five modalities studied, the value of $\mathrm{BOD}_{5} / \mathrm{COD}$ ratio does not exceed 0.2 from which all the leachate collected is stable.

Table 2. Physicochemical characteristics of sewage leachate

\begin{tabular}{l|c|c|c|c|c}
\hline & Soil & Soil $+1 \% \mathrm{~S}$ & Soil $+5 \% \mathrm{~S}$ & Soil $+25 \% \mathrm{~S}$ & $100 \% \mathrm{~S}$ \\
\hline $\mathrm{pH}$ & 7.60 & 7.65 & 7.76 & 7.61 & 7.98 \\
\hline $\mathrm{EC}(\mathrm{mS} / \mathrm{cm})$ & 2.38 & 2.97 & 3.08 & 11.60 & 15.17 \\
\hline $\mathrm{Sal} .(\mathrm{g} / \mathrm{L})$ & 0.86 & 1.12 & 1.19 & 5.59 & 7.72 \\
\hline $\mathrm{Ca}(\mathrm{mg} / \mathrm{L})$ & 212.26 & 274.23 & 349.10 & 686.57 & 369.94 \\
\hline $\mathrm{Mg}(\mathrm{mg} / \mathrm{L})$ & 43.93 & 84.08 & 96.81 & 447.27 & 184.15 \\
\hline $\mathrm{Na}(\mathrm{mg} / \mathrm{L})$ & 58.75 & 67.75 & 46.50 & 240.90 & 587.50 \\
\hline $\mathrm{K}(\mathrm{mg} / \mathrm{L})$ & 27.37 & 15.69 & 26.60 & 238.30 & 486.66 \\
\hline $\mathrm{SO} \mathrm{H}_{4}(\mathrm{mg} / \mathrm{L})$ & 169.22 & 243.37 & 527.75 & 1939.43 & 3837.65 \\
\hline $\mathrm{Cl}(\mathrm{mg} / \mathrm{L})$ & 232.19 & 200.40 & 174.01 & 315.70 & 390.38 \\
\hline
\end{tabular}


Fig. 1. $B O D_{5}$ and $C O D$ of leachates $(\mathrm{mg} / \mathrm{L})$

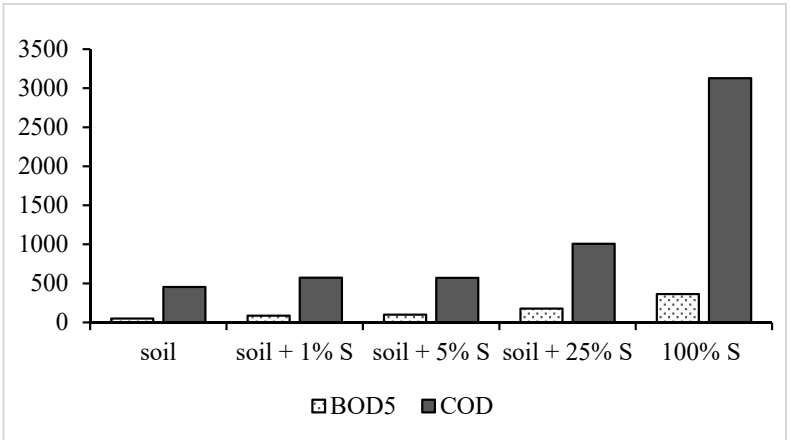

\section{Nitrogen and phosphorus compounds}

The nitrogen compounds $\left(\mathrm{NO}_{3}, \mathrm{NH}_{4}, \mathrm{TKN}\right)$

The concentrations of $\mathrm{NO}_{3}$, TKN and $\mathrm{NH}_{4}$ in the percolates of sewage sludge were determined (Fig. 2). The nitrate concentration $\left(\operatorname{max~} \mathrm{NO}_{3}=640.9 \mathrm{mg} / \mathrm{L}\right)$ was higher than ammonium concentration $\left(\operatorname{max~NH} \mathrm{N}_{4}=36.2 \mathrm{mg} / \mathrm{L}\right.$ ). Similarly, for nitrogenous compounds, their content in the percolation water increased in parallel with the increase in the sludge content in the solid substrates. The nitrate content in the percolate increased from 114.95 $\mathrm{mg} / \mathrm{L}$ for soil $+1 \%$ S to $627 \mathrm{mg} / \mathrm{L}$ for soil $+25 \%$ S. Leaching sludges induced by rainwater enrich the percolate with nitrates, which could contaminate the groundwater, as well as the surface waters inducing their eutrophication.

The high concentrations of $\mathrm{NO}_{3}$ found in the percolates of the soil + sludge mixtures and in the sludge modality can be attributed to i) the leaching of the $\mathrm{NO}_{3}$, which already exists in the solid substrates of the sludge, and ii) the mineralization of the organic nitrogen contained in the sludge. This later generates $\mathrm{NO}_{3}$ via a biologic mediated oxidation of the released ammonium $\left(\mathrm{NH}_{4}\right)$ with a transient production of $\mathrm{NO}_{2}$ as reported by Laudelout (1990). Due to their negative charge, nitrates are not retained by soil clay colloids and can be easily washed away by rainwater and thus contaminate the natural environment, and, eventually, the ground waters (Atteia, 2015).

The organic content in the leachate (NTK) is also determined in this study. The sludge percolates have high content of NTK. This content was $539 \mathrm{mg} / \mathrm{L}$ in sewage sludge leachate, which is 38 times higher than the concentration found in soil leachate (Fig. 2). This strong increase can be attributed to the increase in the amount of leached nitrogenous organic matter. These data are supported by the recent study showing elevated concentrations of organic compounds (either susceptible to biological degradation or not) and ammoniacal nitrogen substances in the leachate (Mor et al., 2006).

Ammonium levels, however, have remained low, presumably because of its low stability and rapid conversion to other nitrogenous forms $\left(\mathrm{NO}_{2}, \mathrm{NO}_{3}\right)$.

Fig. 2. Concentrations of $\mathrm{NO}_{3}, \mathrm{TKN}, \mathrm{NH}_{4}$ in sewage sludge leachate $(\mathrm{mg} / \mathrm{L})$

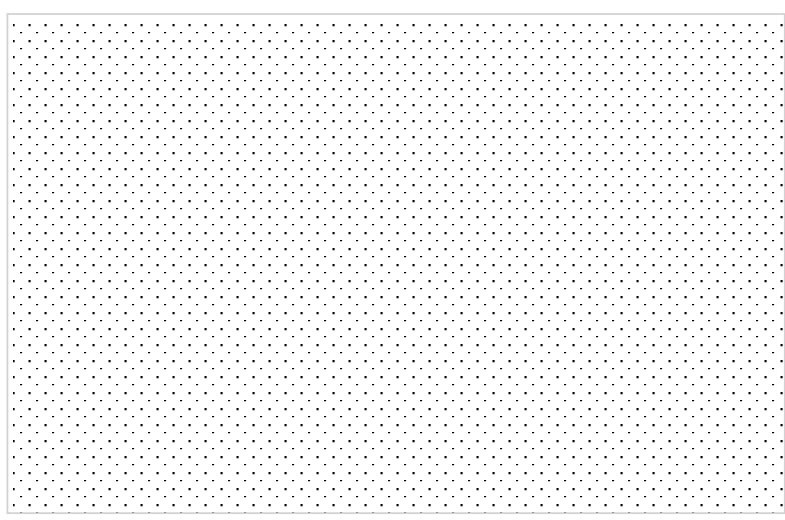

The phosphorous compounds $\left(\mathrm{PO}_{4}, \mathrm{TP}\right)$

The leached amounts of the phosphate ion $\left(\mathrm{PO}_{4}\right)$ and total phosphorus (TP) vary from $0.1 \mathrm{mg} / \mathrm{L}$ to $5.8 \mathrm{mg} / \mathrm{L}$ for $\mathrm{PO}_{4}$ and from $1.2 \mathrm{mg} / \mathrm{L}$ to $16.2 \mathrm{mg} / \mathrm{L}$ for the TP (Fig. 3). The leached concentrations of $\mathrm{PO}_{4}$ and TP from the sludge were respectively 5 and 9 times higher than those leached from the soil (Fig. 3). Indeed, phosphorus from sludge is likely to migrate in the soil solution by leaching or diffusion (Vanden Bossche, 1999).

Fig. 3. Concentration of leached $T P$ and $P O_{4}(\mathrm{mg} / \mathrm{L})$

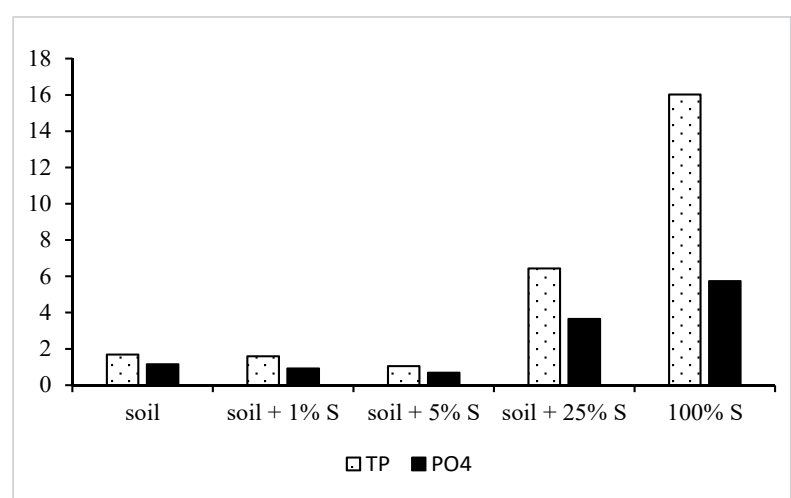


Phosphates were the main compounds of TP present in the column effluents, as reported by Łuczkiewicz (2006). Rain water drains soluble and particulate phosphorus from soil or sludge. Despite the high rate of $\mathrm{PO}_{4}$ and TP leached, the amounts are less significant in comparison with the amount of nitrates. These data are consistent with the previous findings indicating that phosphorus is less easily leached than nitrates and ammonium (Lavelle, 2007).

\section{Heavy metals}

The results show that the concentrations of heavy metals found in the leachates of the five studied modalities were markedly high by $2-5$ folds when the soil was mixed with sludge at 25\% (Fig. 4). Zinc and copper were the most mobilized metals. These data indicate that the sludge may pollute the ground and surface water with heavy metals by several folds depending on the amount of the sludge mixed with the soil.

Fig. 4. Concentration of heavy metals in leachate $(\mu \mathrm{g} / \mathrm{L})$ depending on the percentage of the sludge (S) in the soil

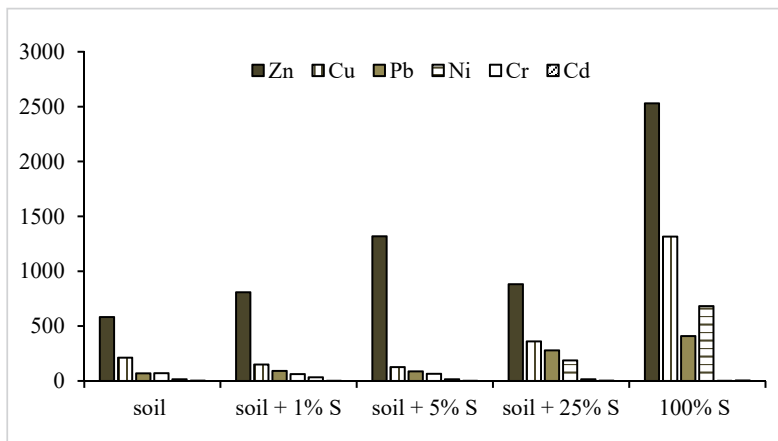

Because heavy metals mobility in soils is negatively correlated with $\mathrm{pH}$ (Robertson and Blowes, 1995; Geohring et al., 2001), the $\mathrm{pH}$ of the sludge-soil mix seems enforcing the retention of heavy metals. Therefore, the leachates $\mathrm{pH}$ varies from to 7.6 to 7.98 . The high $\mathrm{pH}(7 \leq \mathrm{pH} \leq 10)$ at the surface and slightly neutral $(6 \leq \mathrm{pH} \leq 7)$ at depth seems to favour the retention of the heavy metals (Kouame et al., 2006) by the adsorption mechanism (Swift and McLaren, 1991; Kouame et al., 2006).

Several studies have shown that heavy metals from sludge are not completely immobilized within solid soil fractions, but some of these metals can travel into the solution (Camobreco et al., 1996; Richards et al., 1998).
Thus, the biodegradation of sludge contributes to the supply of metals, resulting in greater leaching of heavy metals in the sludge modality. More heavy metals then pass into solution for this modality. Zinc is considered the most mobile and bioavailable among cationic heavy metals (Kiekens, 1995; Fjällborg et al., 2005). Cadmium and chromium were the least mobilized metals. In fact, the sludge would play a retention role for $\mathrm{Cd}$ and $\mathrm{Cr}$. These metals could then be immobilized within stable organometallic complexes.

\section{Characteristics of the solid substrates of the percolation test}

At t0, prior to the run of the percolation test, it was noted that the addition of the sludge to the soil with percentages of 1 to $25 \%$ did not affect all the $\mathrm{pH}$, which remained almost constant (Table 3). Indeed, the $\mathrm{pH}$ values of the modalities were close to neutrality and showed that these modalities favoured the assimilation of the nutrients. However, the electrical conductivity increased in parallel with the increase in the sewage rate, from $291 \mu \mathrm{S} / \mathrm{cm}$ for the soil modality to $4150 \mathrm{mS} / \mathrm{cm}$ for the soil $+25 \%$ of sludge; similar results were according to the findings of other authors (Dridi and Toumi, 1999; Bipfubusa et al., 2006; Amadou, 2007; Bahri and Annabi, 2011). Total phosphorus, $\mathrm{PO}_{4}$ and $\mathrm{NH}_{4}$ levels were also improved following sludge addition. Spreading of sludge will have a fertilizing effect of the soil and, therefore, would increase the crop yield, promote the growth of herbaceous species in natural environment and ultimately reduce the rate of erosion.

After one year ( $t 1)$ since the percolation test installation, the five modalities showed, on the one hand, a decrease in electrical conductivity, which can be explained by the leaching of ions by rain water and decreasing in $\mathrm{TP}$ and $\mathrm{PO}_{4}$ contents due to the mineralization of the organic matter and the leaching of the latter by rainwater, respectively (Table 3). Furthermore, $\mathrm{NH}_{4}, \mathrm{NO}_{3}$ and $\mathrm{PO}_{4}$ levels decreased in soil and in mixtures of 1 to $25 \%$ of sludge with soil, due to their dominant leaching. Whereas they increased for the sludge modality due to the mineralization of organic nitrogen into ammonium followed by the nitrification process. However, the $\mathrm{NO}_{3}$ level decrease from 1360.95 to $682.06 \mathrm{mg} / \mathrm{kg}$, and from 1482.8 to 863.25 $\mathrm{mg} / \mathrm{kg}$, and from 1354.62 to $1069.77 \mathrm{mg} / \mathrm{kg}$, for $0 \%, 1 \%$, $5 \%$, and $25 \%$ of the sludge-soil mixture, respectively. 
Table 3. Physical and chemical characteristic of solid substrates of percolation test at to and t1

\begin{tabular}{|c|c|c|c|c|c|c|c|}
\hline & & $\mathrm{pH}$ & $\mathrm{EC}^{\mathrm{a}}$ & $\mathrm{NO}_{3}{ }^{\mathrm{b}}$ & $\mathrm{NH}_{4}{ }^{\mathrm{c}}$ & $\mathrm{TP}^{\mathrm{d}}$ & $\mathrm{PO}_{4}{ }^{e}$ \\
\hline \multirow{2}{*}{ Soil } & to & 7.95 & 291 & 1360.95 & 8.61 & 848.02 & 84.56 \\
\hline & $\mathrm{t} 1$ & 7.82 & 169 & 682.06 & 5.95 & 376.29 & 82.79 \\
\hline \multirow{2}{*}{ Soil + 1\% S } & to & 7.95 & 334 & 1482.8 & 20.18 ** & 872.18 & 119.29 \\
\hline & $\mathrm{t} 1$ & 7.92 & 170.4 & 863.25 & 5.1 & 351.83 & 85.77 \\
\hline \multirow{2}{*}{ Soil + 5\% S } & to & 7.83 & $601^{\text {** }}$ & $938.42^{*}$ & $33.74^{*}$ & 990.56 & 190.56 \\
\hline & $\mathrm{t} 1$ & 7.75 & 196.6 & 864.05 & 6.63 & $762.55^{\star}$ & 89.69 \\
\hline \multirow{2}{*}{ Soil $+25 \%$ S } & to & $7.25^{\star}$ & $4150^{\star \star \star}$ & 1354.62 & $38.44^{\star \star}$ & 1224.91 & $362.4^{*}$ \\
\hline & $\mathrm{t} 1$ & 7.52 & $558^{*}$ & $1069.77^{*}$ & $17.09^{*}$ & $728.42^{*}$ & 104.49 \\
\hline \multirow{2}{*}{$100 \% \mathrm{~S}$} & to & $6.92^{* *}$ & $4550^{* *}$ & $892^{*}$ & 11.25 & 1275.65 & $688.56^{* *}$ \\
\hline & $\mathrm{t} 1$ & 6.97 & $3090^{* * *}$ & $3266.28^{\star *}$ & $64.39 * *$ & $1069.08^{*}$ & $332.2^{*}$ \\
\hline
\end{tabular}

a: $\mu \mathrm{S} / \mathrm{cm} ; \mathrm{b}, \mathrm{c}, \mathrm{d}$, e: $\mathrm{mg} / \mathrm{kg}$; *: the difference is considered significant when $\mathrm{p}<0.05$

$\left.{ }^{*}, p<0.05 ;{ }^{* *}, p<0.01,{ }^{* *}, p<0.001\right)$ using unpaired Student $t$ test to compare sample

values vs control group - soil alone

\section{Conclusion}

The leaching test carried out in this study provides an explanation of how the rain allows percolation of the most mobile chemical compounds from sewage sludge applied to land. The percentage of the added sludge to soil determines the leaching amount of nitrogen, phosphate, salt compounds and heavy metals, mainly zinc and copper. Undoubtedly, this percolation influences the chemical composition of shallow aquifers, especially when soils are characterized by high water permeability. Hence, together with heavy metals, nutrient compounds should be regarded as limiting factors for sewage sludge land application. Also, the effects of short-term addition of sludge studied in this experiment indicate that this addition has a beneficial fertilizing effect on the soil for

\section{References}

Amadou H. (2007) Modélisation du séchage solaire sous serre des boues de stations d'épuration urbaines, Thèse doctorat, Université de louis pasteur-Strasbourg1. Available at: https:// publication-theses.unistra.fr/public/theses_doctorat/2007/ AMADOU_Haoua_2007.pdf

Arisily T.A.A. and Hajji A. (2020) Technologie de séchage solaire des boues des stations d'épuration des eaux usées et son im- the short term in the absence of significant drain by rain water. Therefore, it is of great interest to expand the use of sludge in non-agricultural environments such as forest soils or degraded soils with the aim of replanting or increasing wood production.

However, in order to protect the quality of ground and surface water, this study provides evidence of deleterious effects of WTP-sludge on soil and water quality, as well as a strong rational for the necessity of a careful monitoring, management and storage of sludge produced by sewage treatment plants. Regulatory measures for setting the conditions and technical requirements have to be implemented to ensure the protection of environment and population's health.

pact sur la gestion des boues au Maroc. Revue Marocaine des Sciences Agronomiques et Vétérinaires 8(1): 57-66.

Atteia 0. (2005) Chimie et pollutions des eaux souterraines, Paris, France: TEC et DOC Lavoisier.

Bahri H. and Annabi M. (2011) Effet des boues urbaines sur la mouillabilité et la stabilité structurale d'un sol cultivé. Étude et Gestion des Sols 18(3): 7-15. 
Bhalla B., Saini M.S. and Jha M.K. (2013) Effect of age and seasonal variations on leachate characteristics of municipal solid waste landfill. International Journal of Research in Engi-nneering and Technology 2(6): 732-745.

Bipfubusa M., N'Dayegamiye A. and Antoun H. (2006) Evaluation des effets des boues mixtes fraiches et de leurs composts sur les rendements des cultures et leur nutrition minérale. Agrosols 17(1): 65-72.

Bourg A.C.M. and Loch J.P.G. (1995) Mobilization of heavy metals as affected by $\mathrm{pH}$ and redox conditions. In: Salomons W. and Stigliani WM. (1995) Biogeodynamics of Pollutants in Soils and Sediments: Risk Assessment of Delayed and Non-linear Responses, Springer. https://doi.org/10.1007/978-3-642-79418-6_4

Camobreco V.J., Richards B.K., Steenhuis T.S., Peverly J.H. and Mcbride M.B. (1996) Movement of heavy metals through undisturbed and homogenized soil columns. Soil Science 161(11): 740-750. https://doi.org/10.1097/00010694-199611000-00003

Cesar R., Silva M., Colonese J., Bidone E., Egler S., Castilhos Z. and Polivanov H. (2012) Influence of the properties of tropical soils in the toxicity and bioavailability of heavy metals in sewage sludge-amended lands. Environmental Earth Science 66: 22812292. https://doi.org/10.1007/s12665-011-1449-2

Chaudri AM., Allin MG., Barbosa-Jefferson VL., Nicholsson FA., Chambers BJ. and Mcgrath SP. (2000) A study of the impacts of $\mathrm{Zn}$ and $\mathrm{Cu}$ on two rhizobial species in soils of a longterm field experiment. Plant and soil 221: 167-79. https://doi. org/10.1023/A:1004735705492

Christensen T.H., Kjeldsen P., Bjerg P.L., Jensen D.L., Christensen J.B., Baun A., Albrechtsen H-J. and Heron G. (2001) Biogeochemistry of landfill leachate plumes. Applied Geochemistry 16: 659-718. https://doi.org/10.1016/S0883-2927(00)00082-2

Dewil R., Baeyens J, Roels J. and Van De Steene B. (2008) Distribution of Sulphur Compounds in Sewage Sludge Treatment. Environmental Engineering Science 25 (6): 879-886. https:// doi.org/10.1089/ees.2007.0143

Dong Y., Lu H., Li J. and Wang C. (2015) The Leachate Release and Microstructure of the Sewage Sludge under the Anaerobic Fermentation. Journal of Chemistry 2015: 9 pages. https://doi. org/10.1155/2015/901021

Dounavis A., Koumalas A., Barampouti E.M. and Mai S. (2019) Leachates from Landfill Sites in Thessaloniki, Greece: Effect of Aging. Environmental Research, Engineering and Management 75(4): 30-39. https://doi.org/10.5755/j01.erem.75.4.23073

Dridi B. and Toumi C. (1999) Influence d'amendements organiques et d'apport de boues sur les propriétés d'un sol cultivé. Etude et gestion des sols 1(6): 7-14.
EPA-ROC (1994) The standard Methods for determination of heavy metals in soils and plants, National institute of environmental Analysis of EPA-ROC, Taipei, Taiwan, ROC.

FJällborg B., Ahlberg G., Nilsson E. and Dave G. (2005) Identification of metal toxicity in sewage sludge leachate. Environment International 31: 25-31. https://doi.org/10.1016/j.envint.2004.06.004

Fuentes A., Loréns M., Sáez J., Aguilar M.I., Ortuño J.F. and Meseguer V.F. (2004) Phytotoxicity and heavy metals speciation of stabilised sewage sludge. Journal of Hazardous Materials 108: 161-169. https://doi.org/10.1016/j.jhazmat.2004.02.014

Geohring L.D., McHugh O.V., Walter M.T., Steenhuis T.S., Akhatar M.S. and Walter M.F. (2001) Phosphorus transport into subsurface drains by macrospores after manure applications: Implications for best manure management practices. Soil Science 166(12): 896-909. https://doi.org/10.1097/00010694200112000-00004

Gigliotti G., Giusquiani P.L. and Businelli D. (2001) A long-term chemical and infrared spectroscopy study on a soil amended with municipal sewage sludge. Agronomie 21: 169-178. https://doi.org/10.1051/agro:2001115

Gutenmann W.H., Rutzke M., Kuntz H.T. and Lisk D.J. (1994) Elements and polychlorinated biphenyls in sewage sludges of large cities in the United States. Chemosphere 28: 725-728. https://doi.org/10.1016/0045-6535(94)90225-9

Keller C., Mcgrath S.P. and Dunham S.J. (2002) Trace metal leaching through a soil grassland system after sewage sludge application. Journal of Environmental Quality 31: 1550-1560.

Keeney D.R. and Nelson D.W. (1982) Nitrogen-inorganic forms. In: Methods of soil analysis, Part 2. Chemical and Microbiological Properties, USA: Page A.L, pp 643-700. https://doi. org/10.2134/agronmonogr9.2.2ed.c33

Kiekens L. (1995) Zinc. In: Heavy Metals in Soils, London, UK: Blackie Academic \& Professional, pp 284-305. https://doi. org/10.1007/978-94-011-1344-1_13

Kominko H., Gorazda K. and Wzorek Z. (2017) The possibility of organo-mineral fertilizer production from sewage sludge. Waste and Biomass Valorization 8 (5): 1781-1791. https://doi. org/10.1007/s12649-016-9805-9

Kouame I. K., Gone D. L., Savane I., Kouassi E. A., Koffi K., Goula B.T.A. and Diallo M. (2006) Mobilité relative des métaux lourds issus de la décharge d'Akouédo et risque de contamination de la nappe du Continental Terminal (Abidjan - Côte d'Ivoire). Afrique Science 02(1): 39-56.

Lambkin D., Nortcliff S. and White T. (2004) The importance of precision in sampling sludges, biowastes and treated soils in 
a regulatory framework. Trac-Trends in Analytical Chemistry 23(10-11): 704-715. https://doi.org/10.1016/j.trac.2004.08.008

Laudelout $H$. (1990) Les bases quantitatives de la production et du mouvement des nitrates. In: Proceeding of the International Symposium Nitrates, agriculture, eau, Paris, 7-8 Novembre 1990, pp 139-156.

Lavado RS., Rodriguez M., Alvarez R., Taboada MA. and Zubillaga MS. (2007) Transfer of potentially toxic elements from biosolid-treated soils to maize and wheat crops. Agriculture Ecosystems \& Environment 118:312-318. https://doi.org/10.1016/j. agee.2006.06.001

Lavelle P. (2007) Cycle des principaux nutriments (azote, phosphore et soufre) à l'échelle planétaire. In: Cycles biogéochimiques et écosystèmes continentaux, Rapport sur la science et la technologie $N^{\circ}$ 27, EDP Science, France, pp 49-66.

Lee A.H. and Nikraz H. (2014) BOD:COD Ratio as an Indicator for Pollutants Leaching from Landfill. Journal of Clean Energy Technologies 2(3): 263-266. https://doi.org/10.7763/JOCET.2014.V2.137

Lehmann J. and Chroth G. S. (2003) Chapter 7. Nutrient leaching. In; Schroth G. and Sinclair F. L. Trees, crops and soil fertility, Oxfordshire, United Kingdom: CAB International, pp 151-166. https://doi.org/10.1079/9780851995939.0151

Łuczkiewicz A. (2006) Soil and Groundwater Contamination as a Result of Sewage Sludge Land Application. Polish Journal of Environmental Studies 15(6): 869-876.

Lyazidi R., Hessane M.A., Filali Moutei J., Bahir M. and Ouhamdouch S. (2019) Management of water resource from semiarid area by elaborating database under GIS: case of Gareb-Bouareg aquifer (Rif, Morocco). Arabian Journal of Geosciences 12(11): 1-14. https://doi.org/10.1007/s12517-019-4513-y

Martínez F., Cuevas G., Calvo R. and Walter I. (2003) Biowaste effects on soil and native plants in a semiarid ecosystem. Journal of Environmental Quality 32: 472-479. https://doi.org/10.2134/ jeq2003.4720

Mor S., Ravindra K., Dahiya R.P. and Chandra A. (2006) Leach $\neg$ ate characterization and assessment of groundwater pollu-tion near municipal solid waste landfill site. Environmental monitoring and assessment 118(1-3): 435-456.https://doi. org/10.1007/s10661-006-1505-7

Mosquera-Losada MR., Munoz-Ferreiro N. and Rigueiro- Rodriguez A. (2010) Agronomic characterisation of different types of sewage sludge: policy implications. Waste Management 30(3): 492-503. https://doi.org/10.1016/j.wasman.2009.09.021

Netherlands Enterprise Agency (2018) Business Opportunities report for reuse of wastewater in Morocco. Ministry of foreign affairs. Available at: https://www.rvo.nl/sites/default/files/2018/06/ Business-opportunities-report-for-reuse-of-wastewater-in-morocco.pdf.

Olsen S.R. and Sommers L.E. (1982) Phosphorus. In: Miller R.H., Keeney D.R. Eds, Methods of soil analysis, Part 2, Agronomy Monograph 9, American Society of Agronomy. Madison, Wisconsin, USA: Page A.L., pp 403-430. https://doi.org/10.2134/ agronmonogr9.2.2ed.c24

Quasim S. R. and Chiang W. (1994) Sanitary Landfill Leachate: Generation, Control, and Treatment, Lancaster, Pennsylvania, USA: Technomic Publishing Co. Inc.

Richards B.K., Steenhuis T.S., Peverly J.H. and MC Bride M.B. (1998) Metal mobility at an old, heavily loaded sludge application site. Environmental pollution 99: 365-377. https://doi. org/10.1016/S0269-7491(98)00011-6

Robertson W.D. and Blowes D.W. (1995) Major lon and Trace Metal Geochemistry of an Acidic Septic System Plume in Silt. Ground Water 33(2): 275-283. https://doi.org/10.1111/j.1745-6584.1995. tb00282.x

Robinson H.D. and Lucas J.L. (1985) Leachate attenuation in the unsaturated zone beneath landfills: instrumentation and monitoring of a site in southern England. Water Sciences Technology 17: 477-492. https://doi.org/10.2166/wst.1985.0153

Rodier J. (1984) L'analyse de l'eau (eaux naturelles, eaux résiduaires, eau de mer), Paris, France : Dunod Edition.

Self-Davis M.L., Moore P.A. and Joern B.C. (2000) Determination of water-and/or dilute salt-extractable phosphorus. In: Methods of phosphorus analysis for soils, sediments, residuals, and waters, Southern Cooperative Series Bulletin 396: 22-26.

Sommers L.E., Tabatabai M.A. and Nelson D.W. (1977) Forms of sulphur insewagesludge. Journal of Environmental Quality 6: 42 46. https://doi.org/10.2134/jeq1977.00472425000600010011x

Sort X. and Alcañiz J. M. (1999) Effects of sewage sludge amendment on soil aggregation. Land Degradation and Development 10(3): 3-12. https://doi.org/10.1002/(SICI)1099145X(199901/02)10:1<3::AID-LDR305>3.0.CO;2-0

SWANA (1997) Leachate Generation, Collection and Treatment at Municipal Solid Waste Disposal Facilities. Publication No. GR-D 0535 , Solid Waste Association of North America, Silver Springs, Maryland.

Swift R. and McLaren R. (1991) Micronutrient adsorption by soils and soil colloids. In: Bolt G.H., Boodt M.F., Hayes M.H.B. and Mcbride M.B. Interactions at the soil colloid-soil solution interface, Dordrecht: Kluwer Academic Publications, pp 257-292. https://doi.org/10.1007/978-94-017-1909-4_9

Tardat -Henry M. and Beaudry J-P. (1992) Chimie des eaux, Quebec, Canada : Les éditions Le Griffon d'argile. 
Vanden Bossche H. (1999) Devenir du phosphore apporté sur les sols et risques de contamination des eaux de surface $321 \mathrm{p}$, Thèse doctorat, Université de Rennes. Available at: https://tel. archives-ouvertes.fr/tel-00003703v2.

Vettorazzo S. C., Amaral F. C. S., and Chitolina J. C. (2001) Nutrient leaching potential following application of papermill lime-sludge to an acidic clay soil. Revista Brasileira de Ciência do Solo 25(3): 755-763. https://doi.org/10.1590/S010006832001000300025
White C.S., Loftin S.R. and Aguilar R. (1997) Application of biosolid to degraded semiarid rangeland: Nineyear responses. Journal of Environmental Quality 26: 1663-1671. https://doi. org/10.2134/jeq1997.00472425002600060029x

Wu C., Li W., Wang K. and Li Y. (2015) Usage of pumice as bulking agent in sewage sludge composting. Bioresource Technology 190: 516-21. https://doi.org/10.1016/j.biortech.2015.03.104 